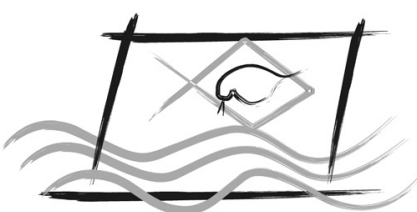

ECOTOX - BRASIL

\title{
An evaluation of Allonais inaequalis Stephenson, 1911 (Oligochaeta: Naididae) as a toxicity test organism
}

\author{
J.J. Corbi*, G.R. Gorni \& R.C. CORreA \\ Departamento de Hidráulica e Saneamento (SHS), Escola de Engenharia de São Carlos (EESC), Universidade de São Paulo - USP, C.P. \\ 359, CEP 13566-590, São Carlos, SP, Brazil.
}

(Received November 19, 2014; Accept March 06, 2015)

\begin{abstract}
Oligochaeta are suitable for assessing the effects of contaminants on the environment, but in Brazil, few studies have been developed for the use of native species in toxicity bioassays. Given the increasing interest in this research area by the environmental agencies for the usage of species of aquatic Oligochaeta in ecotoxicological studies, in addition to the need for greater biological knowledge of native species, the present work aimed to establish a protocol to be used in ecotoxicological bioassays using the native species Allonais inaequalis. The Naididae A. inaequalis (Stephenson, 1911) was first described as Nais pectinata var. inaequalis Stephenson, 1911. The distribution of this species has been mentioned for several environments in Brazil. This paper presents results from tests on the sensitivity of the species to $\mathrm{KCl}\left(\mathrm{LC}_{50}\right)$ and to zinc chloride $\left(\mathrm{LC}_{50}\right)$, the general characteristics of the species and laboratory breeding methods. Laboratory rearing, the collection and identification of the organism are easy when compared to other organisms such as Chironomus xanthus, a species commonly used in toxicity bioassays. It is expected that this work will assist in the use of $A$. inaequalis species for routine water monitoring protocols for tropical environments.
\end{abstract}

Keywords: bioassays; Oligochaeta; sediment; water monitoring.

\section{INTRODUCTION}

Toxicity tests are laboratory assays performed under specific and controlled experimental conditions used to estimate the toxicity of substances, industrial effluents and environmental samples (e.g. water or sediment from rivers, streams and lakes). In these laboratory tests, organisms are exposed to different sample concentrations and the toxic effects are observed and quantified (Costa et al., 2006). Likewise, toxicity tests are required tools for assessing water quality and pollution of wastewater, since only physical and chemical analysis, such as chemical oxygen demand (COD), biochemical oxygen demand (BOD), metals concentrations and other organic or inorganic substances are unable to distinguish between substances that affect biological systems and the environment. Therefore, they are not sufficient to evaluate the potential risk of environmental contaminants
(Sotero-Santos et al., 2007; Rodgher et al., 2010; Novelli, 2010; Campagna et al., 2013).

Ecotoxicological bioassays are conducted to evaluate the effect of toxic chemicals on aquatic organisms in the ecosystem. Toxic effects may be visible at different levels of organization, from cellular structures to individuals, populations and communities. Aquatic toxicity tests are widely used because aquatic ecosystems are major receptacles of contaminants dumped directly into water bodies through discharge of effluents, emitted to atmosphere or deposited into aquatic sediments. In the same way, the necessity of more accurate information about toxicity tests with sediment dwelling organisms has grown, especially when native species are considered.

In recent years, aquatic Oligochaeta have been used in ecotoxicological bioassays. Aquatic Oligochaeta are exposed to toxic substances through food and body contact with 
sediment, interstitial water and water columns (Smith et al., 1991). Chapman (2001) points out that oligochaetes are suitable for such environmental assessments because they are keystone species in aquatic ecosystems; a number of species are cosmopolitan; they have been used in many chronic toxicity tests; are often exposed to contaminants through the water and sediments; many species are needed to enable testing bioaccumulation biomass; they can be easily grown and treated and can withstand unique physical and chemical conditions. Similarly, Smith et al. (1991) indicate that the habitat make this aquatic group an important class of organisms for application in assessing toxicity of aquatic sediments. However, only a few species of Oligochaeta have been studied in detail for toxicological sediment bioassays. This is the case of Lumbriculus variegatus (Müller) (Lumbriculidae), Pristina leidyi Smith (Naididae) and Tubifex tubifex (Müller) (Naididae) (USEPA, 2000; ASTM 2005; OECD 2008; Lobo, 2014) and the recent work conducted by Lobo \& Espíndola (2014), using Branchiura sowerbyi.

According to some authors, species of Oligochaeta could be better exploited in ecotoxicological and bioaccumulation bioassays mainly because of its large biomass compared to other aquatic organisms (Lobo, 2014; Chapman, 2001). In 2008, the "Organization for Economic Cooperation and Development" (OECD), responsible for issuing various protocols for the regulation of research, published in its standards (Guideline 315) an indication for the use of Oligochaeta Branchiura sowerbyi in bioassays for bioaccumulation. The literature indicates that Naididae species can be an important pathway for the transfer of energy and toxicants from low to high trophic levels. It has been suggested that oligochaetes might be an important source of food for fish and immature species of aquatic invertebrates such as caddisflies, dragonflies, and beetles (Smith et al., 1991; Alves \& Strixino, 2000; Alves et al., 2006).

Thus, the purpose of this paper is to present the results of a series of experiments with Allonais inaequalis designed to assess its suitability for usage as a toxicity test organism. Methods for laboratory culture, sensibility, toxicity tests and diagnoses of species are described.

\section{MATERIALS AND METHODS}

\section{Allonais inaequalis}

As diagnostic structures, A. inaequalis has body length ranging from 3 to $9 \mathrm{~mm}$ ( 37 to 85 segments), without pigmentation. The region above the prostomium has a rounded shape, and the eyes and the proboscis are absent. The dorsal chaetae begin in segment VI and consist of 1-2 capillaries chaetae accompanied by 1-2 needles chaetae. The needles chaetae are pectinate, with uneven teeth side associated with 1-4 intermediate thinner teeth. The ventral chaetae are bifid with slightly proximal node. These can occur in bundles of 5 to 8 chaetae (Fig. 1). This species has a wide distribution, with records in North America, South America, Africa, Australia and Southeast Asia (Brinkhurst \& Jamieson, 1971).
The distribution of the species has also been recorded in several environments in Brazil, for example, in Araraquara town - São Paulo State, more specifically in the sediment of Pinheirinho stream (Alves et al., 2006) and in Ribeirão das Cruzes stream, associated with gastropods (Gorni \& Alves, 2006). In the municipalities of Itirapina and Américo Brasiliense (both in São Paulo State), A. inaequalis were found in Dourada pond and in Ribeirão Anhumas reservoir, associated with aquatic macrophytes (Alves \& Gorni, 2007). The species has also been collected in the Amazon River basin in floating vegetation in oxbow lagoons (Shain et al., 2007).

\section{Cultivation of test organisms}

The first individuals of $A$. inaequalis were obtained from water and aquatic sediment samples in ponds located in São Carlos (São Paulo, Brazil), in the Ecological Municipal Park. For cultivation purposes, the specimens were placed in new plastic trays $(25 \times 30 \mathrm{~cm})$, washed with dechlorinated water and deionized water. The trays were filled with deionized water (2 liters) containing $1 \mathrm{Kg}$ of sterilized sediment (sand washed with tap water, dried and placed in an oven at 540 ${ }^{\circ} \mathrm{C}$ for 4 hours), kept at room temperature (between 22 and $28{ }^{\circ} \mathrm{C}$ ) with light aeration ( 1 bubble per second of air) and fed with $20 \mathrm{~mL}$ Tetramim ${ }^{\circledR}$ fish feed $(2 \mathrm{~g}$ to one liter of deionized water). The feed was added at a rate of $20 \mathrm{~mL}$ of solution each culture every seven days. When beginning a new culture, beakers containing $100 \mathrm{~mL}$ of deionized water, $5 \mathrm{~g}$ of sterile sand and $5 \mathrm{~mL}$ of feed solution (Tetramim ${ }^{\circledR}$ ) were used every 7 days. The cultures were maintained by regularly adding maintenance water $(\mathrm{pH} 6.5-7.5$, hardness $12-16 \mathrm{mg} \mathrm{CaCO}_{3}$ and temperature $23-25^{\circ} \mathrm{C}$ ) and replacing $20 \%$ of the old culture with maintenance water every 4 weeks. Culture populations were estimated periodically by subsampling. The $\mathrm{pH}$ values of the samples remained around 7.0 and electrical conductivity values around $20 \mu \mathrm{S} \mathrm{cm}$ with 12:12 h light/dark photoperiod.

\section{Sensibility tests and $\mathrm{LC}_{50}$}

Sensitivity tests for evaluating the quality and sensitivity of cultures of $A$. inaequalis, which consisted of exposing the organisms to different concentrations of a reference substance, were performed. Acute tests with the reference substance potassium chloride $(\mathrm{KCl})$ were carried out during the tests to evaluate the physiological conditions of the organisms, following recommendations of Fonseca \& Rocha (2004).

Acute tests with $\mathrm{KCl}$ were performed using concentrations of $1.5 ; 2.25 ; 3.5 ; 5.0$ and $7.5 \mathrm{~g} \mathrm{~L}^{-1}$. For these tests, $200 \mathrm{~mL}$ of $\mathrm{KCl}$ solution and 6 organisms in each replicate were used, totaling three replicates for each concentration, lasting 96h (Fonseca, 1997). The results were analyzed using the "drc" package (Ritz \& Streibig, 2005) in software "R" (R Core Team, 2014), in order to obtain the $\mathrm{LC}_{50}$ value for potassium chloride.

The following variables were measured in the beginning and in the end of each experiment: $\mathrm{pH}$ and conductivity. During the tests, the temperature $\left(25 \pm 2{ }^{\circ} \mathrm{C}\right)$ and photoperiod 
(12h:12h light:dark) were controlled (Fonseca \& Rocha, 2004; ABNT, 2004).

\section{Zinc chloride toxicity test and $L C_{50}$}

Acute toxicity bioassays using zinc chloride, in order to calculate the median lethal concentration $\left(\mathrm{LC}_{50}\right)$, were conducted. All test solutions were prepared by serial dilutions of a stock solution diluted in deionized water from the cultures of A. inaequalis respective test organism. Thus, for acute toxicity tests with $A$. inaequalis the nominal concentrations were $0.18 ; 5.0$ and $7.0 \mathrm{mg} \mathrm{L}^{-1}$ and the blanks. For the acute toxicity test development, plastic bottles $(500 \mathrm{~mL})$ were used, in which were added $240 \mathrm{~mL}$ of the test solution. The reagent used was zinc chloride - $100 \%$ of Pancreac ${ }^{\circledR}$ mark. Tests were developed using 3 replicates, with six organisms and each lasting 96 hours in the same conditions of temperature and photoperiod for cultivation. The results were analyzed using the software " $\mathrm{R}$ ", in order to obtain the $\mathrm{LC}_{50}$.

The $\mathrm{pH}$ and conductivity were measured in the beginning and in the end of experiment. During the experiment the temperature $\left(25 \pm 2{ }^{\circ} \mathrm{C}\right)$ and photoperiod $(12 \mathrm{~h}: 12 \mathrm{~h}$; light:dark) were controlled (Fonseca \& Rocha, 2004; ABNT, 2004).

\section{RESULTS}

\section{Cultivation of test organisms}

Under the conditions described, the species A. inaequalis was easily cultivated in the laboratory. The results showed that from ten individuals reared in beakers containing $5 \mathrm{~g}$ of sterilized sand, $100 \mathrm{~mL}$ of maintenance water and $5 \mathrm{~mL}$ of feed solution Tetramin ${ }^{\circledR}$, population doubles every 14 days, thus showing good potential for breeding in laboratory and for usage in ecotoxicological bioassays. The results also pointed to low mortality under the considered laboratory conditions. The species also survived in low oxygenation conditions. Some characteristics of the species diagnosis are presented in Figure 1.

\section{Sensibility tests and $\mathrm{LC}_{50}$}

Organisms were collected for testing by removing the aeration from the culture container. The oligochaetes crawled up the sides of the container, where they were easily removed with a Pasteur pipet. Randomized placement of organisms into the treatment replicates was used. Organisms with no apparent transverse fission were exposed to the toxicant under static conditions for a period of $96 \mathrm{~h}$.

Three sensitivity tests to $\mathrm{KCl}$ were performed with $A$. inaequalis. The results for the sensitivity tests are presented in Figure 2 and in Table 1 and it can be seen that the $\mathrm{LC}_{50}$ ranged from 3.55 to $5.36 \mathrm{~g} \mathrm{~L}^{-1}$. In any test performed, the values were higher than the sensitivity range suggested by Fonseca (1997), ranging from 2.6 to $6.4 \mathrm{~g} \mathrm{~L}^{-1}$. The test is acceptable if the control mortality did not exceed $10 \%$.

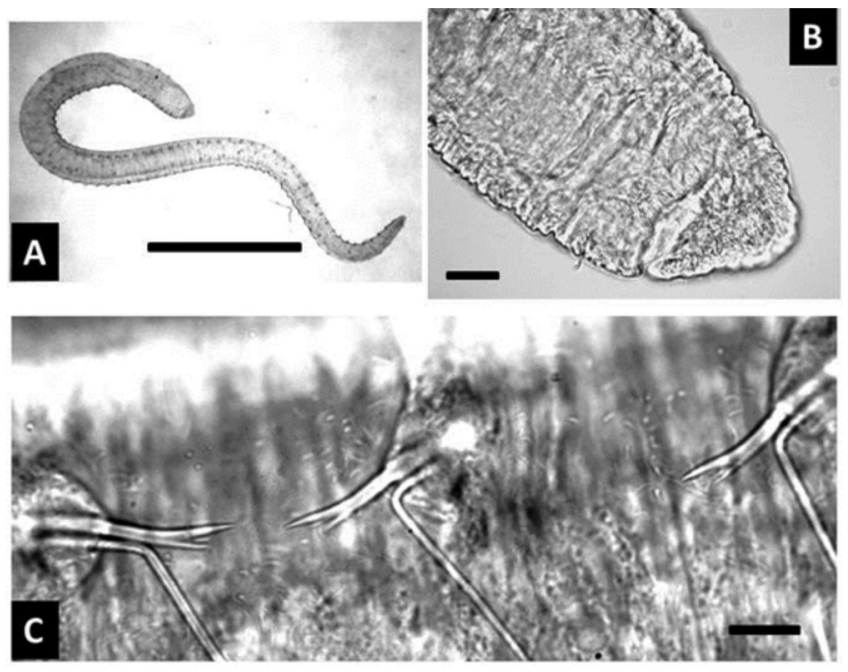

Figure 1 - Allonais inaequalis. A: General overview; B: Prostomium; C: Dorsal needles chaetae. Scale bars: A $=1 \mathrm{~mm}, \mathrm{~B}=150 \mu \mathrm{m}, \mathrm{C}=10 \mu \mathrm{m}$.

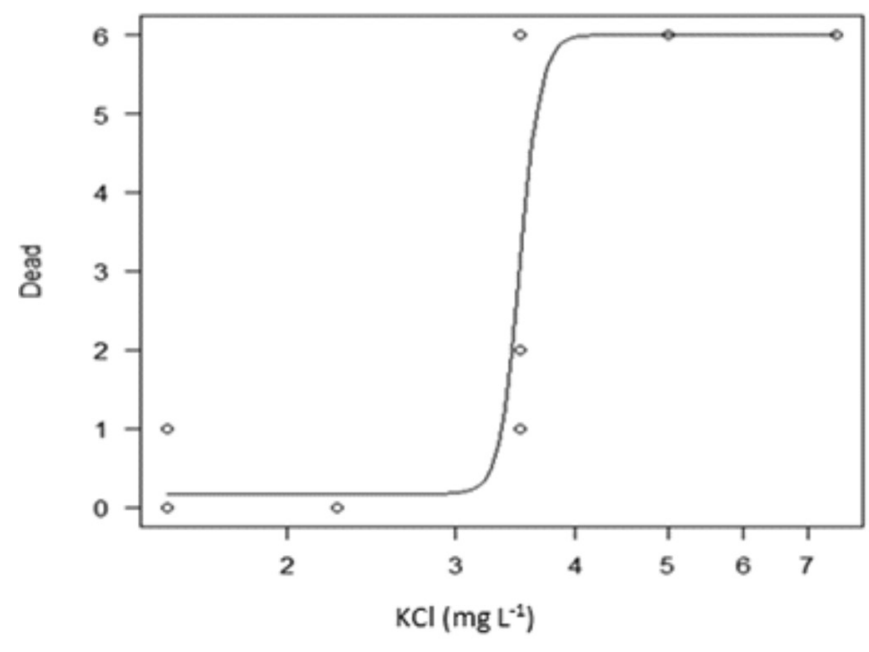

Figure $2-\mathrm{LC}_{50}$ and sensibility test using $\mathrm{KCl}$ with Allonais inaequalis. Detailed results are present in Table 1.

Table 1 - Detailed information about the $\mathrm{LC}_{50}$ tests using $\mathrm{KCl}$ and $\mathrm{ZnCl}_{2}$. Test/values $\quad$ LC $_{50} \quad$ Standard error $\quad$ Lower 95\% CL $\quad$ Upper 95\% CL

\begin{tabular}{lllll}
\hline $\mathrm{KCl}$ & 3.505 & 1.178 & 2.974 & 0.012 \\
\hline $\mathrm{ZnCl}_{2}$ & 0.159 & 0.097 & -0.064 & 0.383 \\
\hline
\end{tabular}

\section{Toxicity test with $Z n$ and determination of $L C_{50}$}

The toxicity tests were performed in same way as the sensitivity tests. Organisms were collected by removing the aeration from the culture container and, when they crawled up the sides of the container, they were easily removed with a Pasteur pipet. Randomized placement of organisms into the treatment replicates was used. Organisms with no apparent transverse fission were exposed to the toxicant under static conditions for a period of $96 \mathrm{~h}$.

The results were expressed in $\mathrm{mg} \mathrm{L}^{-1}$ and they can be seen in Figure 3 and in Table 1. Considering the experimental 
results the average $\mathrm{LC}_{50}$ observed was $0.159 \mathrm{mg} \mathrm{L}^{-1}$. It appears that the low limit ranged from 0.09 to $0.360 \mathrm{mg} \mathrm{L}^{-1}$ and the upper limit from 0.280 to $0.510 \mathrm{mg} \mathrm{L}^{-1}$ (Figure 3). Test results are considered acceptable if the control mortality did not exceed $10 \%$.

\section{DISCUSSION}

Currently, the chemical and physical analyses of sediment have been used in combination with toxicity tests in studies of environmental risk assessment (Costa et al., 2006). In Brazil, the agency responsible for the development of toxicity test protocols is the Brazilian Association of Technical Standards (ABNT). The Society of Environmental Sanitation Technology of the State of São Paulo (CETESB) has also standardized toxicity tests. As pointed out in studies conducted by Costa et al. (2006) organisms used in toxicity tests are especially crustaceans, fish, algae and bacteria.

As noted by Warren et al. (1998), Chironomidae and Oligochaeta are suitable organisms to assess the effects of contaminants on the environment, since their exposure to chemicals occurs not only by water, but also by the intake of sediment. Similarly, considering Brazilian freshwater environments where insects are the dominant species, there is little progress in this field of study, with the exception of the insect Chironomus xanthus, which has currently been used in bioassays of toxicity, due to the development of valuable studies on the biology of the species over the last thirty years (Trivinho-Strixino \& Strixino, 1982; Fonseca \& Rocha, 2004). However, it is noteworthy that besides the lack of knowledge about group biology, not all species of chironomids feed on sediment, since some are predators (Trivinho-Strixino \& Strixino, 1995) and some live within trunks of decaying wood, feeding on these particles and wood. A similar situation is observed for Oligochaeta species, with the exception of a recent work conducted by Lobo \& Espíndola (2014), which presents a proposal for the use of Branchiura sowerbyi species in toxicological bioassays in Brazil, based on a valuable study on the biology of the specie. In this study, the authors suggest

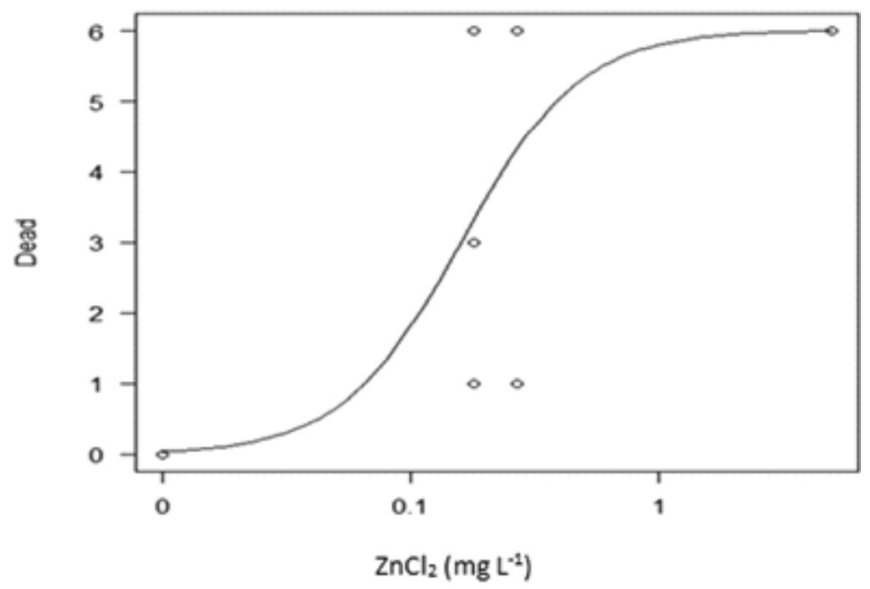

Figure 3 - $\mathrm{LC}_{50}$ toxicity test using $\mathrm{ZnCl}_{2}$ with Allonais inaequalis. Detailed results are present in Table 1. the species $B$. sowerbyi as an option for tests in tropical areas since it is a native species and because of its high individual biomass in comparison with other oligochaete species. Thus, it can be seen that Oligochaeta species have been little used in toxicity bioassays.

Overall, only a few oligochaete species have been studied so far by international agencies for which toxicology test protocols have been established. As pointed out before, this is the case of Lumbriculus variegatus (Müller) (Lumbriculidae), Pristina leidyi Smith (Naididae) and Tubifex tubifex (Müller) (Naididae). As pointed by (Lobo \& Espíndola, 2014), the first species is not native and is typically found in temperateclimate areas while the last one presents a cosmopolitan distribution despite its low frequency in tropical regions.

The species $A$. inaequalis can be easily reared in laboratory conditions and the use of a sterile natural sediment generated good results. The species was sensitive to tests using $\mathrm{KCl}$ wherein the values in the tests were in the range of sensitivity suggested by Fonseca (1997), from 2.6 to $6.4 \mathrm{~g} \mathrm{~L}^{-1}$. Similarly, the species demonstrated sensitivity using zinc chloride for which sensitivity increases the possibility of use of A. inaequalis in toxicity bioassays and in environmental monitoring.

Aquatic oligochaetes could provide this information through cost-effective toxicity tests (Smith et al., 1991). Cultivation and bioassays using Oligochaeta $A$. inaequalis are very promising, considering the small number of research focused on this area, combined with the great interest of research institutions and environmental agencies. The simplicity of cultivation of $A$. inaequalis and ease in obtaining organisms as compared to other test organisms such as Chironomus xanthus, a species commonly used in toxicity bioassays, point to $A$. inaequalis as a species that is able to be included in protocols for evaluating the toxicity of sediment and water in tropical regions.

\section{ACKNOWLEDGEMENTS}

The authors gratefully acknowledge the fruitful suggestions of Professor Pedro P. Corbi and Dra. Vanessa Colombo Corbi. We thank the São Paulo State Research Foundation (FAPESP), for the research fellowship, process number 2013/24268-2.

\section{REFERENCES}

ASTM - American Society for Testing and Materials. 2005. E170605: Standard test method for measuring the toxicity of sedimentassociated contaminants with freshwater invertebrates, $117 \mathrm{pp}$.

ALVES, R. G. \& STRIXINO, G. 2000. Distribuição espacial de Oligochaeta do sedimento de uma lagoa marginal do rio MogiGuaçu-SP. Iheringia, Série Zoologia, 88: 173-180.

ALVES, R. G., MARCHESE, M. R. \& ESCARPINATI, S. C. 2006. Oligochaeta (Annelida, Clitellata) in lotic environments in the state of São Paulo, Brazil. Iheringia, Sér. Zool. 96: 431-435. http://dx.doi.org/10.1590/S1676-06032008000100009.

ALVES, R. G. \& GORNI, G. R. 2007. Naididae species (Oligochaeta) 
associated with submersed aquatic macrophytes in two reservoirs (São Paulo, Brazil). Acta Limnol. Bras. 19: 407-413.

ASSOCIAÇÃO BRASILEIRA DE NORMAS TÉCNICAS - ABNT. 2004. NBR 15088: Ecotoxicologia Aquática - Toxicidade aguda - método de ensaio com peixes. São Paulo.

BRINKHURST, R. O. \& JAMIESON, B. G. M.. 1971. Aquatic Oligochaeta of the World University of Toronto Press, Toronto, Ontario, Canada. 860p.

CAMPAGNA, A. F., RODRIGUES, B. K., NOGUEIRO, R. C., VERANI, N. F., ESPÍNDOLA, E. L. G., \& ALLEONI, L. R. F. 2013. Use of artificial sediment to assess toxicity of chromium on Chironomus xanthus, Danio rerio and Poecilia reticulata. Acta Limnol. Bras. 25:42-53.

CHAPMAN, P. M. 2001. Utility and relevance of aquatic oligochaetes in ecological risk assessment. Hydrobiologia, 463: 149-169. http://dx.doi.org/10.1023/A:1013103708250

COSTA, C. R., OLIVI, P., BOTTA, C. M. R. \& ESPINDOLA, E. L. G. 2008. Toxicity in aquatic environments: discussion and evaluation methods. Quim. Nova, 31: 1820-1830. http://dx.doi. org/10.1590/S0100-40422008000700038

FONSECA, A. L. \& ROCHA, O. 2004. Laboratory cultures of the native species Chironomus xanthus Rempel, 1939 (DipteraChironomidae). Acta Limnol.Bras. 16: 153-161.

GORNI, G. R. \& ALVES, R. G. 2006. Naididae (Annelida, Oligochaeta) associated with Pomacea bridgesii Reeve (Gastropoda, Ampullaridae). Rev. Bras. Zool. 23: 1059-1061. http://dx.doi.org/10.1590/S0101-81752006000400011.

LOBO, H. \& ESPÍNDOLA, E. L. G. Branchiura sowerbyi Beddard, 1892 (Oligochaeta: Naididae) as a test species in ecotoxicology bioassays: a review. 2014. Zoosymposia, 9: 059-069. http:// dx.doi.org/10.11646/zoosymposia.9.1.11

LOBO, H. 2014. Branchiura sowerbyi (Oligochaeta, Naididae) como espécie-teste em bioensaios ecotoxicológicos. $\mathrm{PhD}$ Thesis. Universidade de São Paulo, São Carlos -SP, 117p.

NOVELLI, A., VIEIRA, B. H., CORDEIRO, D., CAPPELINI, L. T .D., VIEIRA, E. M. \& ESPÍNDOLA, E. L. G. 2012. Lethal effects of abamectin on the aquatic organisms Daphnia similis, Chironomus xanthus and Danio rerio. Chemosphere, 86: 36-40. http://dx.doi.org/10.1016/j.chemosphere.2011.08.047

OECD - Organization for Economic Cooperation and Development (2008). 315: Guidelines for the Testing of Chemicals: Bioaccumulation in Sediment-dwelling Benthic Oligochaetes. $32 \mathrm{p}$.

RODGHER, S., ESPÍNDOLA, E. L. G. \& LOMBARDI, A. T. 2010. Suitability of Daphnia similis as an alternative organism in ecotoxicological tests: implications for metal toxicity. Ecotoxicology, 19: 1027-1033. http://dx.doi.org/10.1007/ s10646-010-0484-1

SMITH, P. D., KENNEDY, J. H. \& DICKSON, L. K. 1991. An evaluation of a naidid oligochaeteas a toxicity test organism. Environ. Toxicol. Chem. 10: 1459-1465.

SOTERO-SANTOS, R. B., CARVALHO, E. G., DELLAMANOOLIVEIRA, M. J. \& ROCHA, O. 2008. Occurrence and toxicity of an Anabaena bloom in a tropical reservoir (Southeast Brazil). Harmful Algae, 7: 590-598. http://dx.doi.org/10.1016/j. hal.2007.12.017

USEPA - United States Environmental Protection Agency. 2000. EPA/600/R-99/064: Methods for measuring the toxicity and bioaccumulation of sediment associated contaminant with freshwater invertebrates. $2^{\mathrm{a}}$ ed., Washington D.C., 192p. 